\title{
Gram-Positive Microaerophilic Coccus
}

National Cancer Institute

\section{Source}

National Cancer Institute. Gram-Positive Microaerophilic Coccus. NCI Thesaurus. Code C123472.

Any spherical shaped bacteria that requires oxygen, but is poisoned by high concentrations, and has a peptidoglycan rich cell wall that stains dark purple with the Gram staining technique. 